\title{
アモルファス金属鉄心の低回転速度モータへの適用検証
}

\section{Study of Applicability of Amorphous Core for Low Speed Motors}

\author{
杉山 雄太 ${ }^{* 1}$ (正員)，王 卓男 ${ }^{* 1}$, 榎本 $\quad$ 裕治 ${ }^{* 1}$ (正員)，谷川 茂穂 ${ }^{* 1}$ (正員)
}

Yuta SUGIYAMA (Mem.), Zhuonan WANG, Yuji ENOMOTO (Mem.), Shigeho TANIGAWA (Mem.)

\begin{abstract}
Amorphos metal has very low iron loss and is expected to improve the efficiency of electrical machine such as motors. In general, amorphos cores are thought to be more superior in high speed motors because iron loss increases with frequency and amorphous metal's low iron loss properties are effective in high frequency region. In this report, however, we studied applicability of amorphous cores for low speed axial gap motors and found that the superiority over electric steel 35A300 existed even in low speed motors. We designed the double rotor axial gap motor which the rated output is $750 \mathrm{r} / \mathrm{min}$ and $2.0 \mathrm{~N} \cdot \mathrm{m}$ and the amorphous core motor shows $3 \%$ efficiency superiority over magnetic steel core motor. Also we found that the difference of efficiency gets wider in low torque output.
\end{abstract}

Keywords: amorphous, core, motor, axial gap, ferrite, magnet, synchronous, iron loss, efficiency.

\section{1 緒言}

家庭内電化製品の普及や自動車の電動化の拡大と いったことを背景に，エネルギー消費にモータが占め る割合は増加しつつある。国内では電力消費の $50 \%$ 以 上をモータが消費しており [1], 従って持続可能な社会 を目指す上で,モータの高効率化は重要な意味を持つ。 モータの高効率化はその損失の低減によるが，損失 は大きく鉄損, 銅損, 機械損に分別できる。銅損はモ 一タを構成している巻線の電気抵抗により発生する損 失であり, その低減には界磁電流を不要と寸る永久磁 石界磁モータの採用や, 巻線の占積率を上げて低抵抗 化を図るための角型銅線の採用が有効である。機械損 は軸受部の摩擦や空気抵抗などの機械的な損失をいう。

また鉄損は，モー夕を構成している磁性材料が交流 磁界を受けて内部の磁束密度が変化することに起因す る損失であり，低減には磁性材料の低損失化が不可欠 である。鉄損の低減に関してはモー夕に一般的に利用 されている電磁鋼板に代わってさらに低損失なアモル ファス金属を磁心に利用寸ることで，モータの効率を 上げる検討がなされている。アモルファス金属はその 高い強度と薄い厚みにより鉄心への加工が難しため, 複雑な鉄心形状を持つラジアルギャップモーターの適 用は困難である。一方，アキシャルギャップモータの 鉄心は比較的単純な構造でよいこともあり,アモルフ

連絡先： 杉山 雄太， 于319-1292 茨城県日立市大夕力町 7-1-1, (株)日立製作所日立研究所, e-mail: yuta.sugiyama.fcr@hitachi.com ${ }^{* 1}$ 日立製作所
アス鉄心の適用検討が進められている[2-5]。一般に鉄 損は周波数につれて増大寸るため，モー夕に適用した 場合のアモルファス金属の優位性は電磁鋼板に比較し 板厚が薄く高電気抵抗であることから高回転速度モー 夕程顕著であると考えられ，これらの報告も 1000 $\mathrm{r} / \mathrm{min}$ 以上の高速回転をターゲットとしているが, モー タの利用としてはファン用を初め $1000 \mathrm{r} / \mathrm{min}$ 以下の回 転数での利用も多い。したがって比較的低速回転のモ 一タにおいてアモルファス金属鉄心を適用した場合に 効率がごの程度改善されるかについて検討することは 十分に意味があることと思われる。本報告においては, ファン用を念頭にしたモータを試作し，低速回転域で のアモルファス金属鉄心の優位性について検討した。

\section{2 鉄心}

まず鉄心の製法について記述する。鉄心の材料とし ては Metglas 製アモルファス金属 2605SA1 及び比較の ための電磁鋼板 35A300 を用いた。アモルファス金属 は強度が非常に高く薄いため, 打ち抜き加工による鉄 心への積層は困難である。そこで供給されたリボンを 短冊状に切断しそれを台形状に積層したのち樹脂で固 める方法で鉄心を作成した。積層したコアの構造につ いて Fig. 1 に示す。電磁鋼板についても同様の構造に より鉄心を形成した。このように切断した後積層寸る ことで, 積層時に歪が導入される部分を周辺部の切断 面付近の夕と極めて小さい範囲に止める事が出来るた め, 応力による鉄損増加を避けることが可能となり効 率向上に有利と考えられる。 


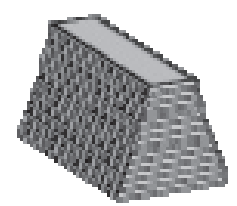

Fig. 1 Structure of Strip-Lamination Core.

Table 1 Cores for Evaluation.

\begin{tabular}{|c|c|c|c|}
\hline No. & Material & Structure & Heat Treatment \\
\hline 1 & $2605 \mathrm{SA} 1$ & Strip Lamination & No \\
\hline 2 & $2605 \mathrm{SA} 1$ & Strip Lamination & Yes \\
\hline 3 & $35 \mathrm{~A} 300$ & Strip Lamination & No \\
\hline
\end{tabular}

またアモルファス金属については, その鉄損低減に 有効と思われる熱処理の影響を見るため, $360^{\circ} \mathrm{C} 1$ 時間, の無磁場中熱処理を積層する前に行った鉄心と，熱処 理を省略した鉄心を準備した。

以上の組合せで 3 種の鉄心を準備した。Table 1 に作 成した鉄心の製法の組合せを示す。

\section{3 モ一夕仕様}

次に作製するモータの仕様について記述する。主な 項目を Table 2 に記載する。まずモータの基本構造であ るが，アモルファス金属を鉄心とするためアキシャル ギャップ構造とし，鉄心をコイルで巻いたステータを 界磁用永久磁石を張り付けたロータで上下を挟むツイ ンロータ型を選択した。構造を Fig. 2 に模式的に示す。 このような構造とすることで, ステータ部ではコイル が巻かれた鉄心以外のヨークが不要となり, 鉄損を最 小化することができる。また鉄心の上下にギャップを 設けた構造とすることで，どちらか片側のみにギャッ プを設けた構造に比べ力が発生するギャップ面積が 2 倍となり，より多くのトルクを稼ぐことが出来，単位 体積当たりのトルクを向上させることが出来る。低回 転数での特性の確認が目的であり, 試作においては定 格回転数は $750 \mathrm{r} / \mathrm{min}$, 定格トルクを $2.0 \mathrm{~N} \cdot \mathrm{m}$ として設 計することにした。このとき出力は $157 \mathrm{~W}$ となる。モ ータの寸法としては, ロータの直径を $130 \mathrm{~mm}$ とし, 非磁性ステンレス鋼製ケースに配置する構造とした。 ロータはヨークと永久磁石とからなり，ヨークは厚み $5 \mathrm{~mm}$ で電磁鋼板製, 永久磁石は厚み $5 \mathrm{~mm}$ の日立金属 製フェライト焼結磁石 $\mathrm{NMF} 12 \mathrm{G}$ 材を用い, 外径 130 $\mathrm{mm}$ 内径 $75 \mathrm{~mm}$ のリング状に配置している。ステータ は積層構造の鉄心にコイルを巻き, 樹脂で固めて一体 にしたものをケースに固定する。
Table 2 Motor Specification.

\begin{tabular}{|c|c|}
\hline Type & Axial Gap \\
\hline Phase number & 3 \\
\hline Stator Coil Number & 12 \\
\hline Pole Number & 14 \\
\hline Rotor Size & $\phi 130 \times 75 \mathrm{~mm}$ \\
\hline Rotor Yoke & Electrical Steel Sheet \\
\hline Permanent Magnet & Sintered Ferrite \\
& $\mathrm{Br}=0.45 \mathrm{~T}$ \\
\hline Stator Coil & $\phi 0.75 \times 372$ turn \\
\hline Air Gap & $0.7 \mathrm{~mm}$ \\
\hline Rated Speed & $750 \mathrm{r} / \mathrm{min}$ \\
\hline Rated Torque & $2.0 \mathrm{~N} \cdot \mathrm{m}$ \\
\hline
\end{tabular}

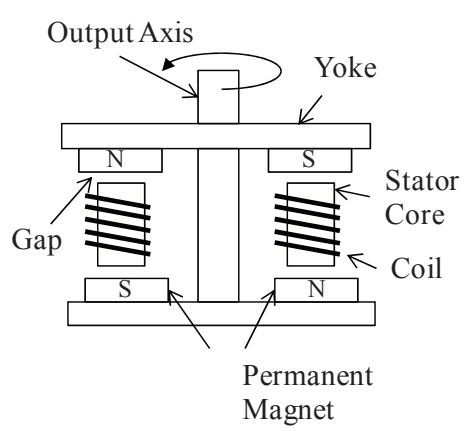

Fig. 2 Structure of Axial Gap Motor.

\section{4 モータ設計結果}

まずモータの設計結果について記述する。設計にお いては鉄心は基準とする電磁鋼板 35A300 の材料デー タを用いて計算した。

\section{1 誘起電圧}

定格回転数におけるモータの無負荷誘起電圧に関し て有限要素法にて計算した值を Fig. 3 に示す。回転数 750 r/min において線間誘起電圧は 157 Vrms である。 またこのとき鉄心内部の最大磁束密度は $0.7 \mathrm{~T}$ とな つた。

\section{2 トルク-電流関係}

モータのトルクと電流特性の関係について有限要 素法を用いて計算した。計算した結果を Fig. 4 に示す。 トルクは電流にほぼ比例して増大しており, 定格の 2.0 $\mathrm{N} \cdot \mathrm{m}$ まで飽和などの兆候は確認できない。トルク 2.0 $\mathrm{N} \cdot \mathrm{m}$ における電流は 0.6 Arms である。飽和している箇 所の有無を確認するため通電電流を $1.0 \mathrm{Arms}$ とした場 合の磁束密度分布を計算したが鉄心部の最大磁束密度 は $0.8 \mathrm{~T}$ 程度であり, 試作の鉄心に用いるいずれの材 料の飽和磁束密度に対しても十分に小さい值である。 


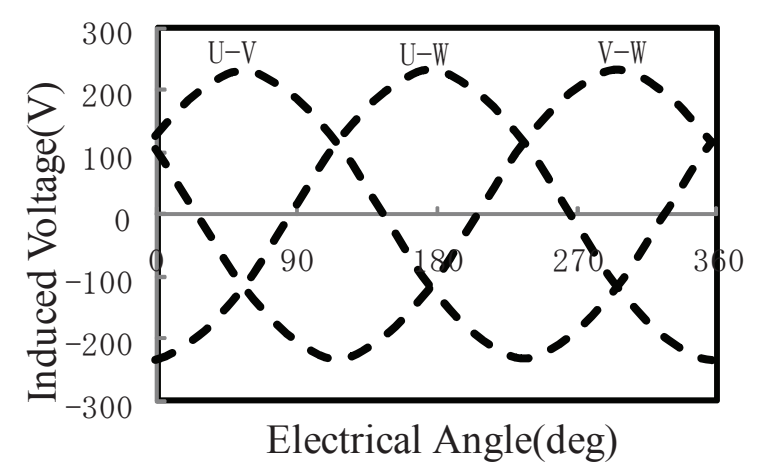

Fig. 3 Calculated Induced Voltage at $750 \mathrm{r} / \mathrm{min}$.

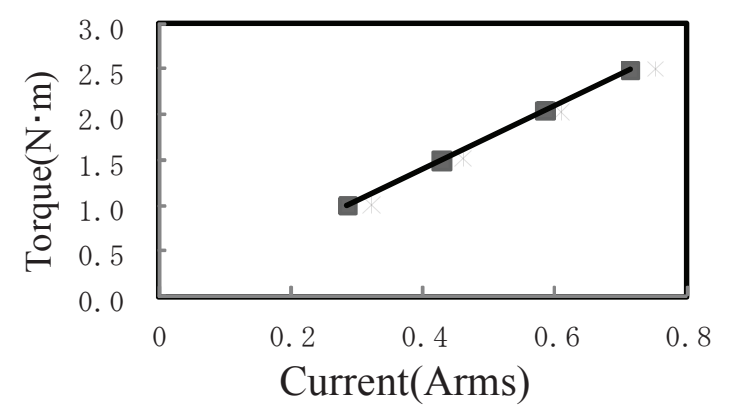

Fig. 4 Torque-Current relation.

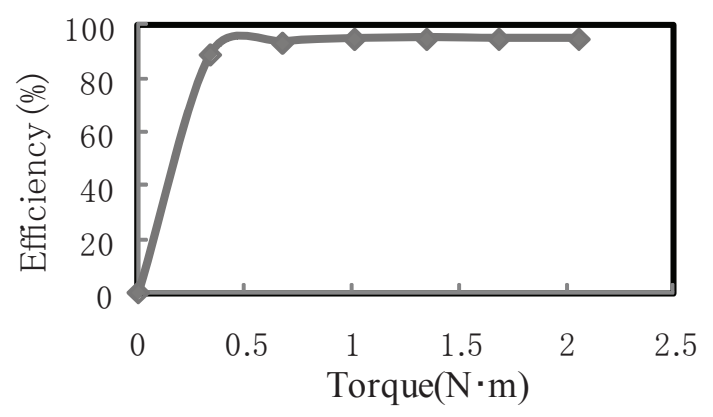

Fig. 5 Motor Efficiency vs. Torque.

また無負荷の場合と比較しても $11 \%$ 程度しか最大磁 束密度は増加しておらず，本試作のようなリラクタン ストルクを利用しないアキシャルギャップモータにお いては, 鉄心内部の磁束密度はほぼ永久磁石の界磁に よって決まることがわかる。

\section{3 モ一夕効率}

Fig. 5 に数值計算で求めたモータ効率を示す。定格 出力において, 銅損 $5.7 \mathrm{~W}$ 鉄損 $2.5 \mathrm{~W}$ が見込まれ効率 は 95\%となった。

\section{5 試作結果}

\section{1 試作モータ外観}

Fig. 6 に試作した鉄心とコイル，それらを樹脂でモ

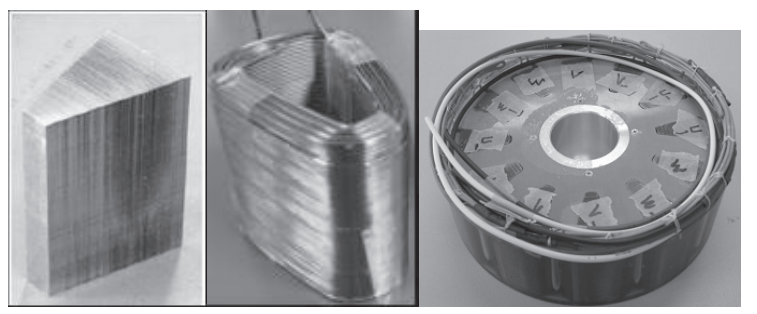

(a) AM Core

(b) Coil

(c)Stator (d) Rotor

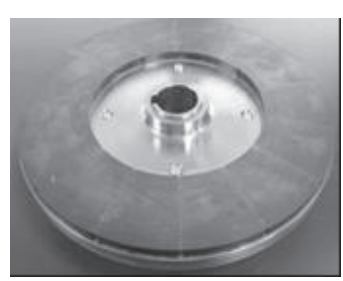

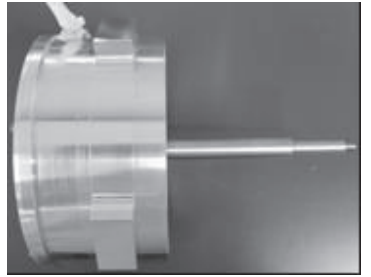

(e) Motor
Fig. 6 Trial Motor

ールドしたステータ及びモータ全体を示す。(a)は鉄心 で，底面積は $350 \mathrm{~mm}^{2}$ で，長さは $40 \mathrm{~mm}$ である。(b) はコイルで， $\phi 0.75$ の銅線を 372 ターン巻いている。 ステータ $(\mathrm{c})$ はこれら鉄心をコイル中心に配置してス テータ保持板で保持し，全体をモールドする構造とし た。コイルの結線は，一相あたり 4 つのコイルを直列 に接続した Y 結線である。(d)がロータであり, 扇状の 磁石をヨークである電磁鋼板製ヨーク上に貼りつけて いる。

\section{2 線間の抵抗及びインダクタンス}

Table 3 に作成したモータの線間の抵抗及びインダ クタンスを示す。インダクタンスはLCRメータ(HIOKI 3522)を用いて測定した。試作したいずれのコアでも, 抵抗及びインダクタンスはほぼ一定となっている。カ タログでは電磁鋼板の初透磁率 $(10 \mathrm{~A} / \mathrm{m})$ が 1000 程度で あるのに対し 2605SA1 は 7000 程, 微分比透磁率も直 流磁束密度を $0.7 \mathrm{~T}$ に印加した状態で電磁鋼板が $10^{4}$ 以 下であるのに対し 2605SA1 は 5x105 以上と大きな違い があるにもかかわらず，鉄心の種類によらずほぼイン ダクタンスが一定であることは，鉄心材料の透磁率の 影響は小さいことを示す。試作したモータの構造が永 久磁石型であるため，インダクタンス測定においては 実質的なギャップがエアギャップ部だけではなく, 永 久磁石もギャップとなりこの部分の磁気抵抗が大きい。 鉄心部の磁気抵抗は高い透磁率からいずれの鉄心でも ギャップ部の磁気抵抗に比べ非常に小さく，したがっ てインダクタンス測定時の磁気回路全体の磁気抵抗は 
ほとんどエアギャップ部と永久磁石部によって決まる ためである。また，いずれの線間でもインダクタンス が同じということから, 試作したモータのバランスが よく取れていることがわかる。

\section{3 誘起電圧}

Table 4 に定格回転数時に線間に誘起される電圧を 示す。誘起電圧も鉄心の材種によらず，ほぼ一定の值 を示す。これも 4.1 節でインダクタンスが一定となっ た理由と同様, 磁気回路の起磁力が同じ永久磁石であ り, 磁気抵抗のほとんどがギャップによってきまるた め，鉄心を通過する磁束が鉄心の種類を変えても同じ であり, 磁束の時間微分で決まる誘起電圧も同じにな ったと考えられる。

\section{4 無負荷損失}

次に無負荷損失を Fig. 7 亿示す。無負荷損失は試作 したモータを外部から駆動し, 駆動トルクと回転数よ り求めた。定格回転数においてアモルファス金属鉄心 で 2.1〜 $2.9 \mathrm{~W}$ ，電磁鋼板鉄心で $4.4 \mathrm{~W}$ となった。この 損失の差は，電磁鋼板とアモルファス金属の鉄損の差 のためであり, アモルファス金属が低損失であること を示すものと考えられる。

Table 3 Coil Inductance \& Resistance.

\begin{tabular}{|c|c|c|c|c|c|c|}
\hline & \multicolumn{2}{|c|}{ U-V } & \multicolumn{2}{c|}{ V-W } & \multicolumn{2}{c|}{ U-W } \\
\hline Cores & $\mathrm{L}(\mathrm{mH})$ & $\mathrm{R}(\mathrm{ohm})$ & $\mathrm{L}(\mathrm{mH})$ & $\mathrm{R}(\mathrm{ohm})$ & $\mathrm{L}(\mathrm{mH})$ & $\mathrm{R}(\mathrm{ohm})$ \\
\hline 2605SA1 noHT & 121.0 & 11.8 & 122.5 & 11.8 & 122.2 & 11.8 \\
\hline 2605SA1 HT & 120.1 & 11.8 & 121.9 & 11.8 & 121.8 & 11.8 \\
\hline 35A300 & 122.2 & 11.9 & 121.0 & 11.9 & 122.3 & 11.9 \\
\hline
\end{tabular}

Table 4 Induced Voltage.

\begin{tabular}{|c|c|c|c|}
\hline Cores & U-V & V-W & U-W \\
\hline 2605SA1 noHT & 157.1 & 156.9 & 156.3 \\
\hline 2605SA1 HT & 156.7 & 156.3 & 154.5 \\
\hline 35A300 & 156.7 & 156.3 & 155.6 \\
\hline
\end{tabular}

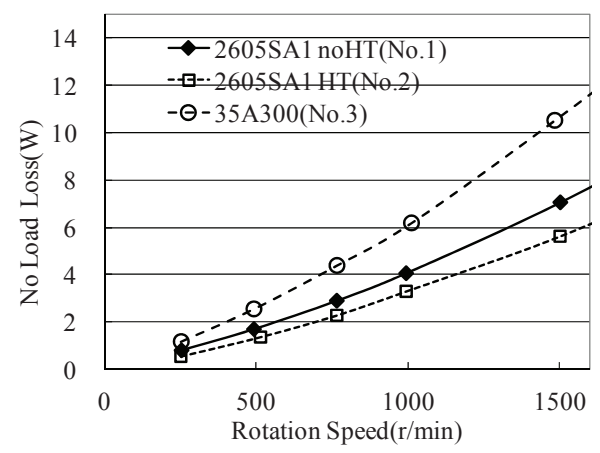

Fig. 7 No Load Loss.
5.5 モータトルク-電流特性

Fig. 8 に定格回転数で測定したモータのトルクと電 流の関係を示す。モータの駆動には安川電機製インバ ータ(A1000)を用いた。いずれの鉄心においてもほぼ同 一のトルク-電流関係を示す。定格出力トルクに必要な 電流は 0.6 Arms となり，ほぼ設計通りである。

出力トルクが $1.0 \mathrm{~N} \cdot \mathrm{m}$ 以上の範囲では，トルクと電 流はほぼ直線関係を示している。これは測定した範囲 では磁気飽和が起きていない事を示している。

低卜ルクの $0.5 \mathrm{~N} \cdot \mathrm{m}$ において, 必要電流が増えて若 干直線からずれるのは, 出力トルクによらない機械損 や鉄損による一定の反トルクを打ち消寸ための電流が 必要なためであると考えられる。無負荷損失の結果か らはその值は電磁鋼板の場合で $56 \mathrm{mN} \cdot \mathrm{m}$, アモルファ スの場合で 27〜 $37 \mathrm{mN} \cdot \mathrm{m}$ である。出力トルクが減少 したためその影響が顕著に現れたためと考えられる。 5.6 モー夕効率

Fig. 9 に試作したモータの定格回転数における効率 とトルクの関係を示した。定格回転数 $750 \mathrm{r} / \mathrm{min}$ 出力 トルク $2.0 \mathrm{~N} \cdot \mathrm{m}$ において最も効率の良い鉄心は No. 1

（2605SA1 熱処理無）となり，96.4\%となった。また No. 2 （2605SA1 熱処理有）においても，96.0\%を達成 している。この結果は熱処理無しの効率より低い結果

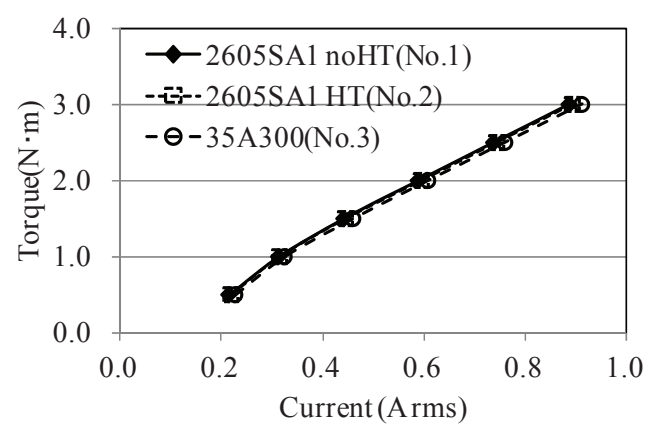

Fig. 8 Motor Torque vs. Current.

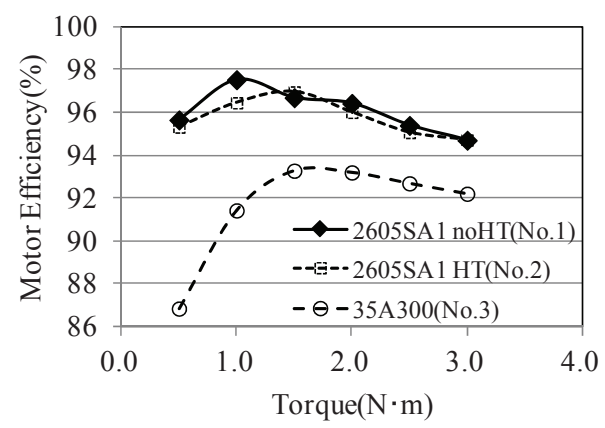

Fig. 9 Efficiency vs. Torque. 
となった。しかし両者の効率差は小さく測定誤差の影 響も考えられ，また無負荷損失の測定では熱処理有り の鉄心の方がわずかながらも低損失であることを示し ていることから, 熱処理無しの方が高効率化に有利と 結論づけることは難しい。一方，電磁鋼板による鉄心 を用いたモータでは 定格出力において効率 $93.2 \%$ と アモルファス鉄心に比べ3\%ほど低くなっている。

設計時に検討したように，定格ではいずれの鉄心材 料においても飽和より十分小さい磁束密度で動作して おり，また鉄心以外の条件については同一であるので 電磁鋼板の効率が低い原因は, 両者の鉄損の違いによ るところが大きいと思われる。このことから，低速回 転モータにおいても, 電磁鋼板製鉄心に比ベアモルフ アス金属製鉄心の優位性が示されたと考える。

また, Fig. 9 において $1.0 \mathrm{~N} \cdot \mathrm{m}$ 以下の低トルク側にお いて特にアモルファス金属製鉄心の優位性が㫫著にな っている。これは低トルクでは駆動電流が小さくなる ため巻線抵抗による銅損は低下寸る一方で, 界磁を永 久磁石で行っているため, 低トルクとなっても鉄心に 流れる磁束は永久磁石による磁束が主流となるため一 定となる。このため無負荷時においても Fig.7 に示す ように一定の鉄損が発生する。このため低トルクでは 鉄損が小さいアモルファス金属の優位性が大きく出た ものと考えられる。

次に Fig. 10 に出力トルクを定格の $2.0 \mathrm{~N} \cdot \mathrm{m}$ と一定に した場合の回転数とモータ効率の関係を示す。測定し た回転数範囲においてアモルファス金属鉄心は電磁鋼 板と比較して約 $3 \%$ 程度高い効率を保っている。低回 転速度においては効率が低下しているが，これはトル クを一定にしたために必要な入力電流も一定となり, 回転数が低下しても銅損が一定であるためである。Fig. 11 にトルクを $2.0 \mathrm{~N} \cdot \mathrm{m}$ と一定にして回転数を変化させ た場合のモータへの入力電流を示す。定格回転数以下 ではほぼ一定であることが確認できる。一方で鉄損は Fig. 7 の無負荷損失からも推定できるように回転数が 低下寸るにつれて小さくなるため, 効率への影響は銅 損が支配的になる。このため前節の一定回転数低トル ク化でアモルファス金属鉄心の優位性が顕著になるよ うな現象は確認されない。

最後に鉄心に $2605 \mathrm{SA} 1$ 熱処理無しのコアを用いた モータでトルクと回転数を変えながら測定したモータ 効率の分布を Fig. 12 に示す。広範囲にわたり効率 $90 \%$ を維持していることがわかる。

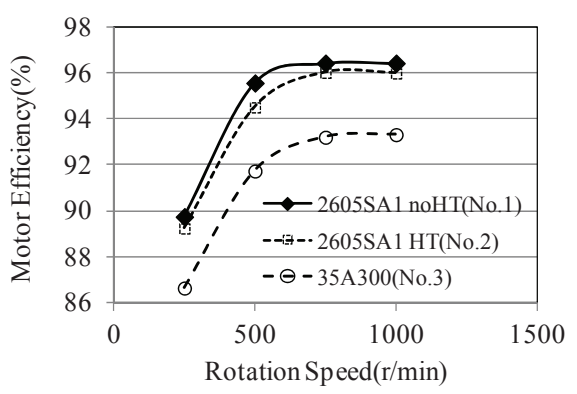

Fig. 10 Efficiency vs. Rotation Speed.

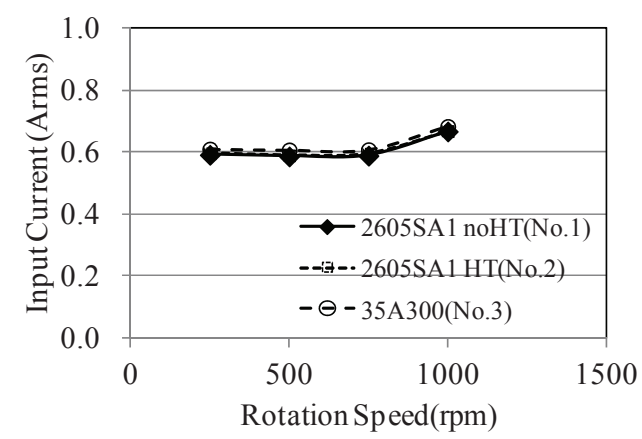

Fig. 11 Input Current vs. Rotation Speed.

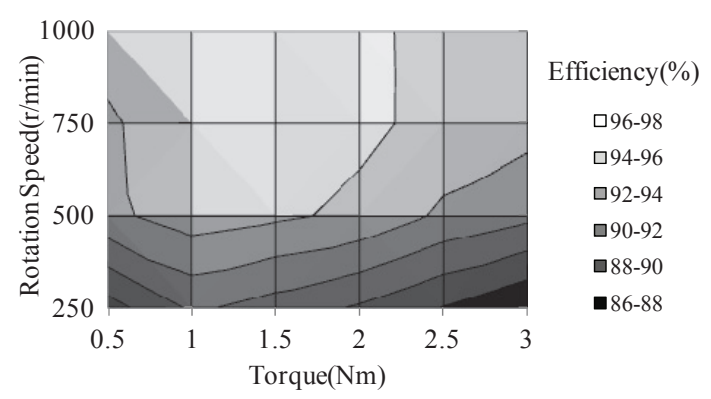

Fig. 12 Efficiency Distribution for 2605SA1 no Heat Treatment Core.

\section{6 結言}

低回転速度ダブルロータ型アキシャルギャップモー タにアモルファス金属(2605SA1 熱処理無し及び熱処 理有り)を鉄心に適用した場合の電磁鋼板(35A300)に 対する優位性を検証し，次の知見を得た。

(1) 今回試作したモータ設計ではアモルファス金属 2605SA1 の熱処理の有無にかかわらず電磁鋼板に 対し定格出力で $3 \%$ 程度の高効率化を達成できた。 一方, アモルファス金属鉄心の熱処理については 本検討で行った熱処理方法では，その有無による モータ特性への影響は小さく, 優位性は確定でき なかった。 
（2）モータの効率は電磁鋼板製鉄心に比ベアモルファ ス金属を鉄心に用いた場合には特に低トルク域で 優位性が顕著になることが確認された。

(3) 一方, 一定トルクで回転数を低下させてもアモル ファス金属鉄心と電磁鋼板鉄心の効率の差にそれ ほど変化はないことが確認できた。

(2012 年 9 月 28 日受付, 2013 年 4 月 26 日再受付)

\section{参考文献}

[1] 電力使用機器の消費電力量に関する現状と近未来の動向 調查，富士経済，2008.

[2] 榎本裕治, 王卓男, 正木良三, 相馬憲一, 谷川茂穂, 板 橋弘光, 産業用アモルファスモータの実用化に関する検 討, 日本 AEM 学会誌, Vol. 19, No. 4, pp.619-624, 2011.

[3] Zhuonan Wang, Ryoso Masaki, Shigeki Morinaga, Yuji Enomoto, Hiromitsu Itabashi, Motoya Ito, Shigeho Tanigawa, Development of an Axial Gap Motor With Amorphous Metal Cores, IEEE Tans. Ind. Appl., Vol. 47, No. 3, pp. 1293-1299, 2011.

[4] 榎本裕治, 王卓男, 正木良三, 相馬憲一, 谷川茂穂, 板 橋弘光, 鉄基アモルファス鉄心を応用した高速度モータ, 日本 AEM 学会誌, Vol. 19, No. 2, pp.384-389, 2011.

[5] G. S. Liew, N. Ertugrul, Wen Liang Soong and J. Gayler, An Investigation of Advanced Magnetic Materials for Axial Field Brushless Permanent Magnet Motor Drives for Automotive Applications, Proceedings of 37th IEEE Power Electronics Specialists Conference, pp.1-7, 2006. 